1. Бондаренко А. І. Напрями вдосконалення координації діяльності органів державного фінансового контролю. Державне будівництво, 2011. № 1 URL: http://www.kbuapa.kharkov.ua/e-book/db/20111/index.html (дата зверенння: 3.09.2021)

2. Закон України «Про Рахункову палату». URL:https://ips.ligazakon.net (дата зверенння: 3.09.2021)

3. Закон України «Про Кабінет Міністрів України».URL: https://zakon.rada (дата зверенння: 3.09.2021)

4. Лопушняк Г, Малецька О, Рибчанська Х. Рахункова палата та їі роль у здійсненні державного фінансового контролю в Україні. Економіка АПК. 2013. № 20(1). С. 123-131.

5. Місюкевич Л.О Основні засади реалізації контрольних функцій рахункової палати у фінансовій сфері в Україні. Публічне управління $і$ адміністрування в Украӥні URL: http://www.pagjournal.iei.od.ua/archives/2020/15-2020/5.pdf (дата зверенння: 3.09.2021)

6. Середа В. В., Кісіль 3. Р., Кісіль В. В. Адміністративне право: навчальний посібник. Львів: ЛьвДУВС, 2014. 520 с.

7. Хаблюк О.А. Яцишин С.Р Аудит ефективності в системі державного фінансового контролю, його суть та необхідність упровадження в Україні. Економіка і суспільство. 2017. №10 С.827-831

8. Табенська Ю. В. Рахункова палата як вищий орган незалежного зовнішнього контролю. Науковий вісник Ужгородського національного університету. 2018. № 19, (3). С. 88-91.

\title{
References
}

1. Bondarenko, A.I. "Directions for improving the coordination of public financial control." State Building, no.1, 2011, kbuapa.kharkov.ua/e-book/db/2011-1/index.html. Accessed 3 Sept.2021

2. On the Accounting Chamber. Law of Ukraine. Ligazakon, ips.ligazakon.net

3. On the Cabinet of Ministers of Ukraine. Law of Ukraine. Verkhovna Rada of Ukraine, zakon.rada. Accessed 3 Sept.2021

4. Lopushnyak, G, Maletska, O, and H. Rybchanska. "Accounting Chamber and its role in the implementation of public financial control in Ukraine.” Economics of agro-industrial complex, no. 20 (1), 2013, pp. 123131.

5. Misyukevych, L.O. "Basic principles of implementation of control functions of the Accounting Chamber in the financial sphere in Ukraine." Public administration in Ukraine, www.pagjournal.iei.od.ua/archives/2020/15-2020/5.pdf. Accessed 3 Sept.2021

6. Sereda, V.V., Kisil, Z.R., and V.V. Kisil. Administrative law: a textbook. Lviv, LvDUVS, 2014.

7. Khabliuk, O.A., and S.R. Yatsyshyn. "Performance audit in the system of public financial control, its essence and the need for implementation in Ukraine.” Economy and society, no.10, 2017, pp.827-831

8. Tabenskaya, Y.V, “Accounting Chamber as the highest body of independent external control." Scientific Bulletin of Uzhhorod National University, no.19 (3), 2018, pp. 88-91.

УДК 336.5.02

doi: 10.15330/apred.2.17.56-67

\section{БЮДЖЕТНА ПОЛІТИКА ФІНАНСОВОГО ЗАБЕЗПЕЧЕННЯ ОБОРОНОЗДАТНОСТІ УКРАЇНИ}

Херсонський національний технічний університет,

Міністерство освіти і науки України,

кафедра фінансів, обліку та оподаткування,

Бериславське шосе, 24, м. Херсон,

73008,Україна,

${ }^{1}$ тел.: 0501304373,

e-mail: larisa1907s@gmail.com,

ORCID: http://orcid.org/0000-0001-7182-2923

2 тел.: 0950987182,

e-mail: svetlanarudyk24@gmail.com

ORCID: http://orcid.org/ 0000-0002-9904-9415 
Актуальні проблеми розвитку економіки регіону. Вип 17. Т.2

Анотація. Стаття спрямована на дослідження особливостей бюджетної політики фінансового забезпечення обороноздатності України протягом 2011-2020 років. Доведено, що внаслідок перманентної недофінансованості, боєздатність української армії на початку російської агресії була зниженою. Встановлено, що негативна тенденція щодо недостатнього фінансування оборонних заходів зберігається і сьогодні, не дозволяючи Україні досягти необхідного рівня захищеності держави, тому питання ефективного формування та використання видатків державного бюджету на оборону не втрачають актуальності.

Метою статті є здійснення моніторингу сучасних реалій фінансування сектору оборони і визначення напрямів оптимізації фінансового забезпечення обороноздатності України в умовах посилення гібридних викликів.

Специфіка наукових завдань, що становлять предмет дослідження, вимагала використання комплексу спеціальних методів, застосування яких допомогло визначити тенденції фінансування оборонних видатків і виявити реальні та потенційні загрози і проблеми фінансового забезпечення обороноздатності України. Рівень забезпечення потреб держави щодо фінансування національної оборони охарактеризовано за трьома напрямами: видатки на оборону за функціональною класифікацією видатків; бюджетні програми Міністерства оборони України за програмною класифікацією; грошове забезпечення військовослужбовців за економічною класифікацією видатків бюджету.

В результаті дослідження доведено, що ключовим аспектом бюджетної політики України щодо фінансового забезпечення іiї обороноздатності є ефективне формування та використання коштів державного бюджету на фінансування Збройних Сил України. В умовах посилення гібридних викликів оборонний бюджет нашої держави має поступово зростати, передбачаючи модернізацію Збройних Сил України шляхом закупівлі озброєння і військової техніки; перехід сектору безпеки і оборони на стандарти НАТО; побудову професійної армії як комплексного процесу, в якому комплектування ЗСУ за контрактом є лише одним 3 елементів; підвищення рівня грошово-матеріального забезпечення та соціального захисту військовослужбовців.

Ключові слова: бюджетна політика, фінансове забезпечення, обороноздатність держави, державний бюджет, видатки на оборону, класифікація видатків.

\title{
Sidelnykova L.P. ${ }^{1}$, Rudyk S.O. ${ }^{2}$ BUDGET POLICY OF FINANCIAL SUPPORT OF UKRAINE'S DEFENSE CAPACITY
}

\author{
Kherson National Technical University, \\ Ministry of Education and Science of Ukraine, \\ Department of Finance, Accounting and Taxation, \\ Beryslavske Highway, 24, Kherson, \\ 73008, Ukraine, \\ ${ }^{1}$ tel.: 0501304373 , \\ e-mail: larisa1907s@gmail.com, \\ ORCID: http://orcid.org/0000-0001-7182-2923
}

\author{
2 tel.: 0950987182, \\ e-mail: larisa1907s@gmail.com, \\ ORCID: http://orcid.org/0000-0001-7182-2923
}

\begin{abstract}
The article is directed at studying the peculiarities of the budget policy of financial support of Ukraine's defense capabilities during 2011-2020. It is proved that due to permanent underfunding, the fighting capacity of the Ukrainian army at the beginning of the Russian aggression was reduced. It is established that the negative trend of insufficient funding for defense measures persists today, not allowing Ukraine to achieve the required level of state protection, so the issues of effective formation and use of state budget expenditures on defense are still relevant.

The purpose of the article is to monitor the current realities of financing the defense sector and
\end{abstract}


identify areas for optimizing the financial support of Ukraine's defense capabilities in terms of increasing hybrid challenges.

The specifics of the scientific tasks that are the subject of the study required the use of a set of special methods, the use of which helped to identify trends in the financing of defense expenditures and identify real and potential threats and problems of financial support of Ukraine's defense capabilities. The level of meeting the needs of the state to finance national defense is characterized by three areas: defense spending according to the functional classification of expenditures; budget programs of the Ministry of Defense of Ukraine according to program classification; financial support for servicemen according to the economic classification of budget expenditures.

As a result of the study, it was proved that a key aspect of Ukraine's budget policy regarding the financial support of its defense capabilities is the effective formation and use of state budget funds to finance the Armed Forces of Ukraine. In the context of intensifying hybrid challenges, the defense budget of our state should gradually grow, providing for the modernization of the Armed Forces of Ukraine through the purchase of weapons and military equipment; the transition of the security and defense sector to NATO standards; building a professional army as a complex process in which the staffing of the Armed Forces under contract is only one of the elements; increasing the level of financial and material security and social protection of servicemen.

Key words: budget policy, financial support, state defense capability, state budget, defense expenditures, classification of expenditures.

Вступ. Однією 3 найважливіших умов існування держави в умовах посилення гібридних загроз та викликів є забезпечення достатніх обсягів фінансування оборонних видатків, які характеризують іï намагання забезпечити сприятливі умови розвитку збройних сил і підтримання рівня їх бойової готовності в необхідному стані.

Видатки на оборону доцільно охарактеризувати як грошові витрати держави на оборонні заходи (утримання збройних сил, розвиток оборонної промисловості, воєнні дослідження, підготовку військових фахівців ) з метою забезпечення державного суверенітету, незалежності, територіальної цілісності, стабільності, захисту населення та країни від будь-яких зовнішніх посягань, а також швидкої локалізації внутрішніх конфліктів. Окрім забезпечення обороноздатності, держава надає повний комплекс соціального захисту військовослужбовців, який націлений на забезпечення продуктивності праці військових та задовольняє їхні потреби.

Водночас, фінансове забезпечення обороноздатності України протягом тривалого часу не було пріоритетним напрямом витрачання бюджетних коштів. До 2014 року відбувалося безсистемне скорочення Збройних Сил України (далі - ЗСУ) та наявного озброєння нижче визначеної потреби, необхідної для забезпечення обороноздатності держави з урахуванням рівня реальних і потенційних загроз у воєнній сфері. Внаслідок перманентної недофінансованості впродовж попередніх років, боєздатність української армії на початку російської агресії виявилася слабкою. Негативна тенденція щодо недостатнього фінансування оборонних заходів зберігається і сьогодні, не дозволяючи Україні досягти необхідного рівня захищеності держави, тому питання ефективного формування та використання видатків державного бюджету на оборону не втрачають своєї актуальності.

Фінансове забезпечення обороноздатності країни в сучасних умовах гібридних викликів має стати одним 3 пріоритетних напрямів використання коштів Державного бюджету України (далі - ДБУ). Обсяги бюджетних ресурсів, спрямованих на фінансування видатків на оборону, залежать від багатьох чинників, але головним 3 них $\epsilon$ військово-політична ситуація в країні. Сучасні тенденції формування та використання оборонних видатків державного бюджету в умовах посилення гібридних загроз та викликів досліджували 3. Варналій, У. Ватаманюк-Зелінська, Є. Карп, Ю. Касперович, О. Кириленко, Ю. Радіонов, Ю. Романовська, Р. Сорока, О. Чеберяко, В. Урбанович. 
Актуальні проблеми розвитку економіки регіону. Вип 17. Т.2

Разом 3 тим, необхідність оптимізації бюджетної політики фінансового забезпечення обороноздатності України в умовах ведення військових дій на Сході країни і тимчасової окупації Криму потребує додаткових розрахунків й обгрунтувань.

Постановка завдання. Метою статті є здійснення моніторингу сучасних реалій фінансування сектору оборони та визначення напрямів оптимізації фінансового забезпечення обороноздатності України в умовах посилення гібридних викликів.

Результати. Сучасна бюджетна політика у сфері видатків має орієнтуватися на виконання пріоритетних завдань соціально-економічного розвитку країни та іiї регіонів, стимулюючи при цьому ділову й інноваційно-інвестиційну активність, розвиток соціальної інфраструктури, збереження існуючих і створення нових робочих місць; гарантуючи забезпечення державного суверенітету i територіальної цілісності. Ключовим аспектом бюджетної політики України щодо фінансового забезпечення іiі обороноздатності $\epsilon$ ефективне формування та використання коштів державного бюджету на фінансування Збройних Сил України. Для повноцінного забезпечення сектору оборони фінансовими ресурсами важливо чітко дотримуватися нормативного визначення потреб для цієї галузі, вчасно проводити бюджетне фінансування згідно 3 бюджетним розписом, ефективно та економно витрачати отримані кошти.

Чинним українським законодавством чітко регламентовано механізм фінансового забезпечення військових видатків. Так, згідно з Бюджетним кодексом України, видатки на оборону здійснюються виключно 3 державного бюджету [1]. Причому видатки загального фонду на заходи, пов'язані з обороноздатністю держави, що здійснюються за рахунок коштів резервного фонду державного бюджету, та видатки на здійснення розвідувальної діяльності $є$ захищеними видатками, тобто їх обсяг не може змінюватися при скороченні затверджених бюджетних призначень.

Щорічно, відповідно до Закону про Державний бюджет України на поточний рік, встановлюється обсяг бюджетних ресурсів держави, які спрямовуються на фінансування національної оборони, причому видатки сектору оборони повинні повністю покривати виконання покладених на цю сферу функцій та складати не менше 3\% запланованого обсягу внутрішнього валового продукту (далі - ВВП).

Для розрахунку рівня забезпечення потреб держави щодо фінансування національної оборони в період 2011-2020 років використаємо підхід Ю. Касперович, яка зазначає, що бюджетне фінансування оборони в Україні доцільно комплексно характеризувати за трьома напрямами: видатки на оборону за функціональною класифікацією видатків; бюджетні програми Міністерства оборони України (далі МОУ) за програмною класифікацією та грошове забезпечення військовослужбовців (далі - ГЗВ) за економічною класифікацією видатків бюджету [2, с. 58].

Отже, насамперед, визначимо обсяги фінансування оборонної функції країни за функціональною класифікацією та співвідношення видатків на оборону до номінального ВВП (табл. 1).

Таблиия 1

Структура видатків Державного бюджету України на оборону, млрд. грн.

Table 1

Structure of expenditures of the State Budget of Ukraine for defense, UAH billion

\begin{tabular}{|l|c|c|c|c|c|c|c|c|c|c|}
\hline \multirow{2}{*}{ Показники } & \multicolumn{10}{|c|}{ Роки } \\
\cline { 2 - 11 } & 2011 & 2012 & 2013 & 2014 & 2015 & 2016 & 2017 & 2018 & 2019 & 2020 \\
\hline ВВП & 1316,6 & 1408,9 & 1454,9 & 1566,7 & 1979,5 & 2383,2 & 2982,9 & 3558,7 & 3974,6 & 4194,1 \\
\hline $\begin{array}{l}\text { Видатки } \\
\text { ДБУ }\end{array}$ & 238,6 & 271,2 & 287,6 & 299,6 & 402,9 & 489,5 & 566,9 & 686,9 & 814,8 & 1197,9 \\
\hline
\end{tabular}


Продовження табл.1

\begin{tabular}{|l|c|c|c|c|c|c|c|c|c|c|}
\hline $\begin{array}{l}\text { Видатки на } \\
\text { оборону }\end{array}$ & 13,1 & 14,5 & 14,8 & 27,4 & 52,0 & 59,4 & 74,4 & 97,0 & 106,6 & 120,4 \\
\hline $\begin{array}{l}\text { - пит. вага у } \\
\text { видатках, \% }\end{array}$ & 5,53 & 5,35 & 5,15 & 9,15 & 12,91 & 14,65 & 13,11 & 14,12 & 13,08 & 10,05 \\
\hline $\begin{array}{l}\text { - пит. вага у } \\
\text { ВВП, \% }\end{array}$ & 1,00 & 1,03 & 1,02 & 1,75 & 2,63 & 3,01 & 2,49 & 2,73 & 2,68 & 2,87 \\
\hline
\end{tabular}

у тому числі:

\begin{tabular}{|l|c|c|c|c|c|c|c|c|c|c|}
\hline $\begin{array}{l}\text { Військова } \\
\text { оборона }\end{array}$ & 10,2 & 11,6 & 11,9 & 24,4 & 47,4 & 53,4 & 67,1 & 87,5 & 102,2 & 115,1 \\
\hline $\begin{array}{l}\text { - пит. вага у } \\
\text { видатках на } \\
\text { оборону, \% }\end{array}$ & 77,86 & 80,00 & 80,41 & 89,05 & 91,15 & 89,90 & 90,19 & 90,21 & 95,87 & 95,60 \\
\hline
\end{tabular}

Джерело: складено авторами на основі [3; 4].

Дані таблиці 1 засвідчують значні коливання обсягів видатків державного бюджету на оборону протягом 2011-2020 років.

У 2011-2013 роках фінансування національної оборони не було пріоритетним напрямом витрачання бюджетних коштів, про що свідчить поступове скорочення частки відповідних видатків $35,53 \%$ до 5,15\% видаткової частини державного бюджету. В той період проросійські сили в уряді свідомо проводили політику щодо перманентного зниження бюджетного забезпечення Збройних Сил України з метою погіршення стану їх бойової готовності та підриву обороноздатності держави, а суспільство, згідно з результатами експертного опитування, проведеного фондом «Демократичні ініціативи» 8-14 липня 2010 року, категорично заперечувало існування таких загроз для суверенітету України як анексія частини їі території іншою державою [5]. Лише певна частка експертів вважала загрозами для державного суверенітету сепаратистські рухи, спрямовані на відокремлення певних територій зі складу України; втрату дієздатності армії та інших силових структур [5].

Свідченням катастрофічного зниження рівня обороноздатності України наприкінці 2013 року стало обмеження боєздатності ЗСУ лише 8 батальйонами, 3 авіаційними ескадрильями і 8 кораблями, загальною чисельністю близько 5 тис. військовослужбовців [6]. Однак вже у 2014 році видатки державного бюджету на оборону зросли майже удвічі - $з$ 14,8 млрд. грн. до 27,4 млрд. грн., що, в свою чергу, склало 9,15\% загального обсягу видатків. У 2015 році видатки на оборону знов збільшилися - до 52,0 млрд. грн., або 12,91\% видаткової частини державного бюджету.

Надалі темпи зростання обсягів видатків на оборону уповільнилися. У 2016 році такі видатки становили 59,4 млрд. грн., або 14,65\% загального обсягу видатків бюджету; у 2017 році - 74,4 млрд. грн., або 13,11\%; у 2018 році - 97,0 млрд. грн., або 14,12\%; у 2019 році фінансування оборони було на рівні 106,6 млрд. грн., або 13,08\% загального обсягу видатків бюджету. Номінальний обсяг видатків державного бюджету на оборону досяг свого максимуму у 2020 році - 120,4 млрд. грн., разом з тим, їхня питома вага значно скоротилася - до 10,05\% фактичних бюджетних асигнувань.

В цілому, протягом останніх десяти років розмір фінансування оборонної галузі в Україні збільшився у 9,2 рази. Зростання обсягів видатків на оборону, починаючи 3 2014 року, стало реакцією нашої держави на початок гібридної війни з боку Російської Федерації, окупації частини Донецької та Луганської областей і анексії Автономної Республіки Крим. 3 початком бойових дій уряд мусив докласти максимальні зусилля для зміцнення обороноздатності країни без шкоди для бюджетного фінансування інших 
функцій держави.

Зазначимо також, що, згідно з функціональною класифікацією, наразі видатки державного бюджету на оборону складаються з трьох підрозділів: військова оборона, цивільна оборона, інша діяльність у сфері оборони (див. табл. 1), причому домінуючу частку складають саме видатки на військову оборону, питома вага яких у загальному складі оборонних видатків збільшилася з 77,86\% у 2011 році до 95,60\% у 2020 році.

Розглядаючи частку видатків державного бюджету на оборону у ВВП, слід зазначити, що в Україні цей показник у 2011-2013 роках знаходився на рівні приблизно 1,00\% ВВП; натомість, у 2014-2016 роках - поступово збільшився до рівня 3,01\% ВВП. У 2017-2020 роках частка видатків на оборону скоротилася і в середньому дорівнювала $2,69 \%$ ВПП.

Динаміка частки видатків Державного бюджету України на оборону у ВВП представлена на рис. 1.

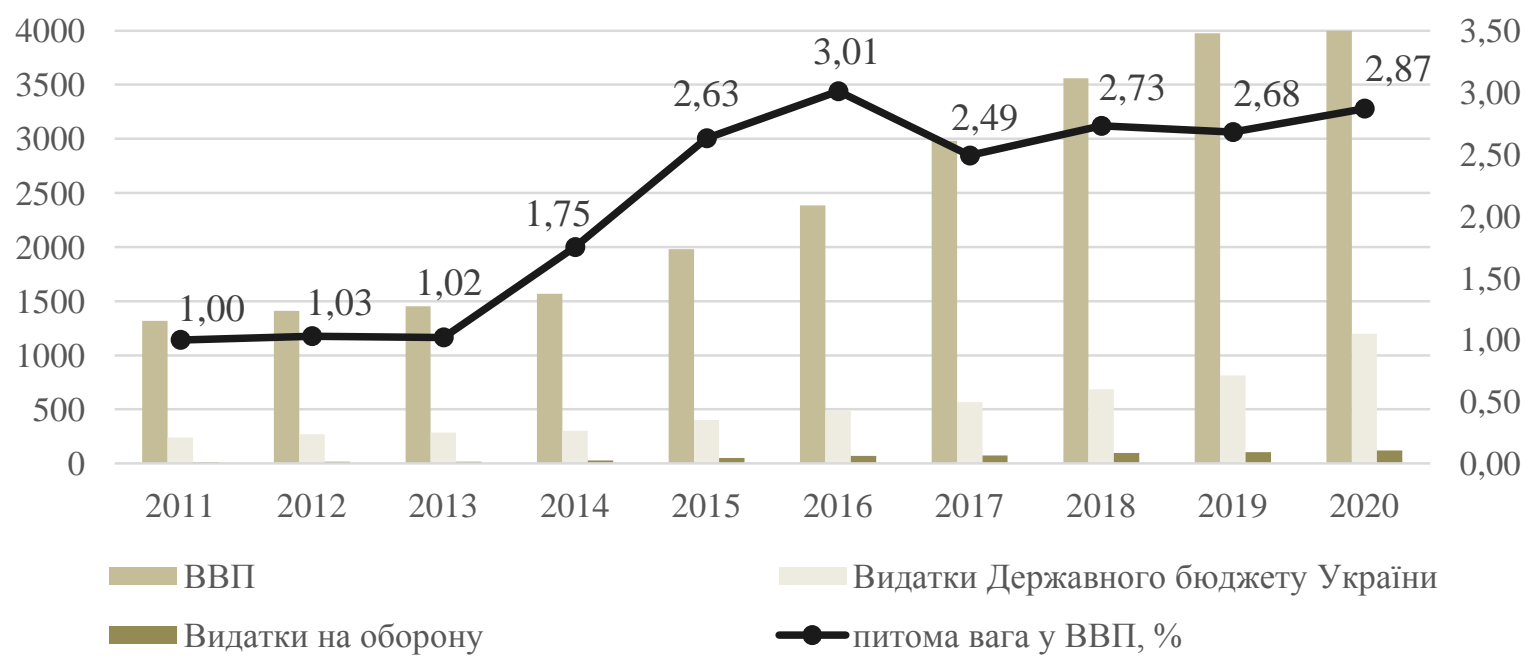

Рис. 1. Динаміка частки видатків на оборону у ВВП, \%

Fig.1. Dynamics of the share of defense expenditures in GDP, \% Джерело: складено авторами на основі [3; 4].

Передумовами стрімкого зростання обсягів фінансування сектору оборони у період 2014-2016 років стали як політичні, так і економічні обставини. Так, у 2014 році відбулася зміна влади та підписання нею Угоди про асоціацію з Європейським Союзом, анексія Криму Російською Федерацією і збройний конфлікт на Сході країни; у 2015 році - спостерігалося різке падіння курсу гривні та обсягів експорту; у 2016 році почала діяти Угода про Поглиблену та всеосяжну зону вільної торгівлі, передбачена Угодою про Асоціацію між Україною та ЄС тощо.

Продовжимо аналіз стану фінансового забезпечення обороноздатності країни оцінкою рівня грошового забезпечення військовослужбовців за економічною класифікацією видатків бюджету, яка передбачає розподіл видатків на поточні (у т.ч. оплата праці), капітальні та нерозподілені видатки. В таблиці 2 розглянемо динаміку грошового забезпечення військових в період 2011-2020 років.

Як свідчать дані таблиці 2, поточні видатки є домінантною складовою видаткової частини Державного бюджету України за економічною класифікацією і складають більше 90\% видатків. При цьому, грошове забезпечення військовослужбовців протягом 2011-2020 років не перевищує 10\% поточних видатків державного бюджету. 
Актуальні проблеми розвитку економіки регіону. Вип 17. T.2

Динаміка видатків на грошове забезпечення військовослужбовців у Державному бюджеті України, млрд. грн.

Table 2

Dynamics of expenditures on financial support of servicemen in the State Budget of Ukraine, UAH billion

\begin{tabular}{|c|c|c|c|c|c|c|c|c|c|c|}
\hline \multirow{2}{*}{ Показники } & \multicolumn{10}{|c|}{ Роки } \\
\hline & 2011 & 2012 & 2013 & 2014 & 2015 & 2016 & 2017 & 2018 & 2019 & 2020 \\
\hline $\begin{array}{l}\text { Видатки } \\
\text { ДБУ }\end{array}$ & 333,5 & 395,7 & 403,5 & 430,2 & 576,9 & 684,9 & 839,5 & 985,9 & 1075,1 & 1288,1 \\
\hline $\begin{array}{l}\text { Поточні } \\
\text { видатки }\end{array}$ & 302,2 & 366,2 & 385,6 & 422,8 & 559,4 & 658,3 & 798,6 & 916,1 & 998,9 & 1193,2 \\
\hline $\begin{array}{l}\text { - пит. вага у } \\
\text { видатках, \% }\end{array}$ & 90,61 & 92,54 & 95,56 & 98,28 & 96,97 & 96,12 & 95,13 & 92,92 & 92,91 & 92,63 \\
\hline \multicolumn{11}{|l|}{ з нux: } \\
\hline Оплата праці & 41,5 & 45,3 & 48,6 & 52,6 & 61,0 & 88,3 & 112,7 & 143,4 & 176,4 & 202,3 \\
\hline $\begin{array}{l}\text { - пит. вага у } \\
\text { поточних } \\
\text { видатках, \% }\end{array}$ & 13,73 & 12,37 & 12,60 & 12,44 & 10,90 & 13,41 & 14,11 & 15,65 & 17,66 & 16,95 \\
\hline $\begin{array}{l}\text { - темп } \\
\text { приросту, \% }\end{array}$ & - & $+9,16$ & $+7,28$ & $+8,23$ & $+15,97$ & $+44,75$ & $+27,63$ & $+27,24$ & $+23,01$ & $+14,68$ \\
\hline \multicolumn{11}{|l|}{ з них: } \\
\hline $\begin{array}{l}\text { Заробітна } \\
\text { плата }\end{array}$ & 23,1 & 26,2 & 27,9 & 26,4 & 25,3 & 33,8 & 48,9 & 67,1 & 75,9 & 84,2 \\
\hline $\begin{array}{l}\text { - пит. вага у } \\
\text { поточних } \\
\text { видатках, \% }\end{array}$ & 7,64 & 7,15 & 7,24 & 6,24 & 4,52 & 5,13 & 6,12 & 7,32 & 7,60 & 7,06 \\
\hline $\begin{array}{l}\text { - темп } \\
\text { приросту, \% }\end{array}$ & - & $+13,42$ & $+6,49$ & $-5,38$ & $-4,17$ & $+33,60$ & $+44,67$ & $+37,22$ & $+13,11$ & $+10,94$ \\
\hline ГЗВ & 18,4 & 19,0 & 20,8 & 26,1 & 35,7 & 54,5 & 63,8 & 76,4 & 100,6 & 118,1 \\
\hline $\begin{array}{l}\text { - пит. вага у } \\
\text { поточних } \\
\text { видатках, \% }\end{array}$ & 6,09 & 5,19 & 5,39 & 6,17 & 6,38 & 8,28 & 7,99 & 8,34 & 10,07 & 9,90 \\
\hline $\begin{array}{l}\text { - темп } \\
\text { приросту, \% }\end{array}$ & - & $+3,26$ & $+9,47$ & $+25,48$ & $+36,78$ & $+52,66$ & $+17,06$ & $+19,75$ & $+31,68$ & $+17,40$ \\
\hline
\end{tabular}

Джерело: складено авторами на основі [4].

Слід зазначити, що в цей період відбувалося стрімке зростання фінансування ГЗВ, причому у 2014-2015 роках - на тлі зменшення розміру заробітних плат у бюджетному секторі, передумовою чого став початок гібридної війни на Сході України у 2014 році та посилення міжнародного конфлікту і введення військового стану у 2018 році.

Отже, підсумуємо, що за десять останніх років на грошове забезпечення військовослужбовців надходило достатньо фінансових ресурсів з боку держави. Разом 3 тим, у 2020 році розмір матеріальної допомоги військовослужбовцям для вирішення соціально-побутових питань було суттєве знижено. Якщо раніше максимальний розмір матеріальної допомоги дорівнював місячному грошовому забезпеченню військового (від 10 тис. грн.), то у 2020 році - лише окладу за військовим званням (530-1500 грн.). 
Ситуація з фінансуванням грошового забезпечення військовослужбовців значно погіршилася у поточному році, адже у видатках державного бюджету на 2021 рік не було враховано додаткову потребу Міністерства оборони України у 5,7 млрд. грн. Ці кошти необхідні для здійснення одноразових обов'язкових видів виплат (допомога на оздоровлення, виплата за перший контракт, матеріальна допомога), виплати додаткової винагороди, яку запроваджено з 29.07.2020 року постановою КМУ № 741 і наказом МОУ № 330, та інших додаткових виплат військовим, передбачених законодавством. Станом на 27.09.2021 року Міністерство оборони України не мало можливості профінансувати такі виплати на суму 2,3 млрд. грн. Водночас, щомісячне грошове забезпечення військовослужбовців ЗСУ виплачується вчасно та у повному обсязі.

Наступним елементом аналізу стану фінансового забезпечення обороноздатності країни у 2011-2020 роках є моніторинг бюджетних програм Міністерства оборони України за програмною класифікацією, яка дозволяє їх розділити на два типи програм.

Перший, або загальний, тип бюджетних програм складають статті видатків державного бюджету, які фінансуються постійно, а саме: утримання Збройних Сил України; медичне лікування особового складу ЗСУ; навчання військових фахівців; розвиток, закупівля, модернізація та ремонт озброєння; інші програми, на які здійснюється фінансування МОУ.

До другого типу бюджетних програм доцільно віднести так звані ситуативні бюджетні програми, які фінансуються протягом одного-двох років. Загалом, в період 2011-2020 років видатки Міністерства оборони України містили 28 бюджетних ситуативних програм. Вони мали різне спрямування та створювалися внаслідок окремих обставин.

Динаміка основних видатків Міністерства оборони України наведена у таблиці 3.

Таблиия 3

Динаміка основних видатків Міністерства оборони України, млрд. грн.

Table 3

Dynamics of the main expenditures of the Ministry of Defense of Ukraine, UAH billion

\begin{tabular}{|c|c|c|c|c|c|c|c|c|c|c|}
\hline \multirow{2}{*}{ Показники } & \multicolumn{10}{|c|}{ Роки } \\
\hline & 2011 & 2012 & 2013 & 2014 & 2015 & 2016 & 2017 & 2018 & 2019 & 2020 \\
\hline $\begin{array}{l}\text { Видатки } \\
\text { ДБУ }\end{array}$ & 333,5 & 395,7 & 403,5 & 430,2 & 576,9 & 684,9 & 839,5 & 985,9 & 1075,1 & 1288,1 \\
\hline MOY & 12,3 & 14,1 & 13,9 & 26,5 & 49,1 & 58,1 & 68,9 & 95,0 & 105,5 & 120,0 \\
\hline $\begin{array}{l}\text { - пит. вага у } \\
\text { видатках, \% }\end{array}$ & 3,69 & 3,56 & 3,44 & 6,16 & 8,51 & 8,48 & 8,21 & 9,64 & 9,81 & 9,32 \\
\hline \begin{tabular}{|l|} 
- темп \\
приросту, \% \\
\end{tabular} & - & $+14,63$ & $-1,42$ & $+90,65$ & $+85,28$ & $+18,33$ & $+18,59$ & $+37,88$ & $+11,05$ & $+13,74$ \\
\hline Апарат МОУ & 12,3 & 14,1 & 13,9 & 26,5 & 49,1 & 58,1 & 68,9 & 94,3 & 104,6 & 118,7 \\
\hline \multicolumn{11}{|l|}{ у тому числі: } \\
\hline $\begin{array}{l}\text { Утримання } \\
\text { ЗСУ }\end{array}$ & 8,7 & 10,5 & 11,0 & 11,9 & 38,5 & 47,3 & 54,5 & 60,8 & 82,3 & 89,0 \\
\hline $\begin{array}{l}\text { - пит. вага у } \\
\text { видатках } \\
\text { МОУ, \% } \\
\end{array}$ & 70,73 & 74,47 & 79,14 & 44,91 & 78,41 & 81,41 & 79,10 & 64,00 & 78,01 & 74,17 \\
\hline \begin{tabular}{|l} 
- темп \\
приросту, \%
\end{tabular} & - & $+20,69$ & $+4,76$ & $+8,18$ & $+223,53$ & $+22,86$ & $+15,22$ & $+11,56$ & $+35,36$ & $+8,14$ \\
\hline $\begin{array}{l}\text { Медичне } \\
\text { лікування }\end{array}$ & 1,0 & 1,0 & 1,0 & 1,0 & 1,4 & 2,0 & 2,0 & 2,5 & 0,0 & 0,0 \\
\hline
\end{tabular}


Актуальні проблеми розвитку економіки регіону. Вип 17. Т.2

Продовження табл.3

\begin{tabular}{|c|c|c|c|c|c|c|c|c|c|c|}
\hline $\begin{array}{l}\text { - пит. вага у } \\
\text { видатках } \\
\text { МОУ, \% }\end{array}$ & 8,13 & 7,09 & 7,19 & 3,77 & 2,85 & 3,44 & 2,90 & 2,63 & 0,00 & 0,0 \\
\hline $\begin{array}{l}\text { - темп } \\
\text { приросту, \% }\end{array}$ & - & 0,00 & 0,00 & 0,00 & $+40,00$ & $+42,86$ & 0,00 & $+25,00$ & - & - \\
\hline $\begin{array}{l}\text { Підготовка } \\
\text { військових } \\
\text { фахівців } \\
\end{array}$ & 0,8 & 0,9 & 0,9 & 0,9 & 1,5 & 2,0 & 2,4 & 2,9 & 0,0 & 0,0 \\
\hline $\begin{array}{l}\text { - пит. вага у } \\
\text { видатках } \\
\text { МОУ, \% }\end{array}$ & 6,50 & 6,38 & 6,47 & 3,40 & 3,05 & 3,44 & 3,48 & 3,05 & 0,00 & 0,0 \\
\hline $\begin{array}{l}\text { - темп } \\
\text { приросту, \% }\end{array}$ & - & $+12,50$ & 0,00 & 0,00 & $+66,67$ & $+33,33$ & $+20,00$ & $+20,83$ & - & - \\
\hline $\begin{array}{l}\text { Закупівля } \\
\text { та ремонт } \\
\text { озброєння }\end{array}$ & 0,3 & 0,9 & 0,7 & 0,7 & 5,7 & 5,8 & 6,7 & 18,4 & 19,2 & 25,6 \\
\hline $\begin{array}{l}\text { - пит. вага у } \\
\text { видатках } \\
\text { МОУ, \% }\end{array}$ & 2,44 & 6,38 & 5,04 & 2,64 & 11,61 & 9,98 & 9,72 & 19,37 & 18,20 & 21,33 \\
\hline $\begin{array}{l}\text { - темп } \\
\text { приросту, \% }\end{array}$ & - & $+200,00$ & $-22,22$ & 0,00 & $+714,29$ & $+1,75$ & $+15,52$ & $+174,63$ & $+4,35$ & $+33,33$ \\
\hline Інше & 1,5 & 0,8 & 0,3 & 12,0 & 2,0 & 1,0 & 3,3 & 10,4 & 4,0 & 5,4 \\
\hline
\end{tabular}

Джерело: складено авторами на основі [4].

Як свідчать дані таблиці 3, видатки на фінансування Міністерства оборони України складали 12,3 млрд. грн. у 2011 році; 14,1 млрд. грн. - у 2012 році; 13,9 млрд. грн. - у 2013 році. Їхня питома вага в середньому становила 3,56\% загального обсягу видатків Державного бюджету України.

Однак, у 2014 році обсяги фінансування МОУ стрімко зросли (майже удвічі порівняно з попереднім роком) та становили 26,5 млрд. грн.; у 2015 році темп приросту склав 85,28\%; сума бюджетних ресурсів, виділена на МОУ, досягла 49,1 млрд. грн., або $8,51 \%$ загального обсягу видатків державного бюджету. Надалі темпи приросту дещо сповільнилися. Загалом, протягом аналізованого періоду розмір фінансування МОУ збільшився на 107,7 млрд. грн.

Основною і найвагомішою бюджетною програмою Міністерства оборони України $\epsilon$ забезпечення діяльності Збройних Сил України та підготовка військ. Другою за значущістю фінансування бюджетною програмою до 2014 року включно було медичне лікування, реабілітація та санаторне забезпечення. 32015 року це місце зайняли видатки на розвиток, закупівлю, модернізацію та ремонт озброєння.

Виходячи 3 того, що рівень видатків державного бюджету на оборону, насамперед, залежить від військово-політичної ситуації в Україні, варто розглянути обсяги та критерії фінансування оборонного сектору за трьома можливими сценаріями.

До першого сценарію розвитку подій, який визначає акценти фінансування видатків на оборону, відноситься «мирний» стан. В такому положенні Україна перебувала у період до 2013 року. Середня частка видатків, яка припадала на забезпечення оборонної функції держави, знаходилася у 2011-2013 роках в середньому на рівні 5,34\% загальної суми видатків державного бюджету.

Наступний період припадає на 2014-2020 роки, коли Україна для відсічі збройної 
агресії з боку Російської Федерації повинна була стрімко долати наслідки хронічної недофінансованості оборонного сектору та зниження iї боєздатності. В середньому, питома вага видатків на оборону складала в ці роки $12,44 \%$ загального обсягу видаткової частини державного бюджету.

Останнім та найбажанішим можливим сценарієм $є$ період, під час якого держава має сформувати висновки на основі досвіду минулих років. Це час, коли остаточно завершаються збройні конфлікти та починається стабільне і оптимальне фінансування кожної функціональної галузі держави. За нашим припущенням, в цей період найоптимальнішим рівнем фінансування національної оборони, у т.ч. соціального захисту військовослужбовців, буде $10-11 \%$ загальної суми видатків Державного бюджету України. Звісно, бажаний сценарій можливий лише за умови ліквідації зовнішніх і внутрішніх загроз територіальній цілісності та недоторканності державних кордонів, суверенітету держави.

Вважаємо за доцільне більш детально розглянути реальні та потенційні загрози і проблеми національної безпеки України, адже саме від їх вирішення, насамперед, залежить гідне функціонування держави (табл. 4).

Таблиия 4

Військово-політичні загрози та проблеми національної безпеки України

Military-political threats and problems of national security of Ukraine

\begin{tabular}{|l|l|}
\hline \multicolumn{1}{|c|}{ Екзогенні (зовнішні) } & \multicolumn{1}{|c|}{ Ендогенні (внутрішні) } \\
\hline $\begin{array}{l}\text { Порушення територіальної цілісності } \\
\text { України з боку іноземних держав }\end{array}$ & $\begin{array}{l}\text { Iснування можливих сепаратистських } \\
\text { рухів з метою ізоляції певних частин } \\
\text { території України }\end{array}$ \\
\hline $\begin{array}{l}\text { Виникнення можливості розповсюдження } \\
\text { зброї масового ураження }\end{array}$ & $\begin{array}{l}\text { Підсилення конфліктів на етнічному або } \\
\text { національному грунті }\end{array}$ \\
\hline Руйнація міжнародних режимів & $\begin{array}{l}\text { Створення і функціонування незаконних } \\
\text { військових збройних формувань }\end{array}$ \\
\hline Міжнародний тероризм & $\begin{array}{l}\text { Неузгоджена військова організація } \\
\text { держави зі своїми цілями та завданнями }\end{array}$ \\
\hline $\begin{array}{l}\text { Втягнення України проти її волі у } \\
\text { військові дії інших держав }\end{array}$ & $\begin{array}{l}\text { Втрата зв’язків України з ринками } \\
\text { озброєння та військової техніки }\end{array}$ \\
\hline $\begin{array}{l}\text { Зростання збройних конфліктів на } \\
\text { території кордонів }\end{array}$ & $\begin{array}{l}\text { Зниження боєздатності внаслідок } \\
\text { низького рівня забезпечення ЗСу }\end{array}$ \\
\hline $\begin{array}{l}\text { Розвідувально-підривна діяльність } \\
\text { іноземних спеціальних служб }\end{array}$ & $\begin{array}{l}\text { Недостатнє фінансове забезпечення } \\
\text { програм МОУ та Зсу }\end{array}$ \\
\hline
\end{tabular}

Джерело: складено авторами на основі [7, с. 70-73].

О. Кириленко досить влучно підкреслює, що події 2014 року, пов'язані зі збройною агресією Російської Федерації проти України, докорінно змінили ставлення до питань посилення обороноздатності та національної безпеки, фінансування Збройних Сил України, проведення реформ у сфері оборони і національної безпеки [8, c. 182]. Тому, на наше переконання, в умовах посилення гібридних викликів оборонний бюджет нашої держави має поступово зростати, передбачаючи модернізацію Збройних Сил України шляхом закупівлі озброєння і військової техніки; перехід сектору безпеки і оборони на стандарти НАТО; побудову професійної армії як комплексного процесу, в якому комплектування ЗСУ за контрактом є лише одним з елементів; підвищення рівня грошово-матеріального забезпечення та соціального захисту військовослужбовців. 
Висновки. Підводячи підсумки, можемо стверджувати, що однією 3 центральних ланок фінансування функцій держави є видатки державного бюджету на оборону, у тому числі на утримання Збройних Сил України. В цьому контексті, не можна не погодитися з Ю. Радіоновим, який зазначає, що в умовах російської агресії необхідно посилювати безпеку й обороноздатність країни, а не фінансувати іiі за залишковим принципом, як це було раніше. Крім того, науковець акцентує увагу, що «наразі доцільно щорічно збільшувати цю статтю витрат, особливо на переозброєння армії, флоту, модернізацію військової техніки, створення нових зразків озброєнь для захисту суверенітету України» [9, с. 61]. Разом з тим, наголошують О. Чеберяко та 3. Варналій, проблема полягає не лише у збільшенні обсягів фінансування, але й у необхідності визначення оптимальної структури видатків у відповідності до державних пріоритетів у сфері національної безпеки [10, с. 144].

Беручи до уваги досвід країн-членів НАТО щодо формування оборонного бюджету, відмови від політики «ручного» управління, створення ефективної системи пріоритетів використання коштів сектору оборони, сформуємо пропозиції щодо вдосконалення об’єкту дослідження.

Отже, на нашу думку, з метою оптимізації бюджетної політики фінансового забезпечення обороноздатності України варто запровадити такі заходи:

- збільшити обсяги видатків державного бюджету на оборону, адже законодавчо визначений показник співвідношення таких видатків до ВВП у розмірі не менше 3\% був виконаний лише у 2016 році;

- забезпечити пріоритетне спрямування бюджетних ресурсів на розвиток Збройних Сил України, які повинні перебувати у стані бойової готовності до виконання завдань за призначенням;

- поліпшити програмно-цільові видатки на оборону за рахунок реформування структури бюджетних програм Міністерства оборони України (повернення бюджетних програм щодо медичного забезпечення та підготовки військових фахівців для підсилення прозорості бюджетного фінансування);

- запровадити у механізм формування оборонного бюджету інструменти довгострокового планування;

- забезпечити перманентне зростання обсягів фінансових ресурсів для підтримки бойової підготовки військових, їх матеріально-технічного забезпечення та підвищення рівня професійної компетентності;

- створити дієвий фінансовий механізм соціального забезпечення військовослужбовців 3 метою своєчасного i повного визначення їхніх потреб та ефективної системи соціального захисту;

- залучати на розвиток військово-оборонного комплексу України прямі іноземні інвестиції та міжнародну технічну допомогу;

- покращити систему фінансового контролю видатків державного бюджету на оборону шляхом створення окремого контролюючого органу.

1. Бюджетний кодекс України: Закон України від 08.07.2010 p. № 2456-VI. Дата оновлення: 29.09.2021. URL: https://zakon.rada.gov.ua/laws/show/2456-17\#Tехt (дата звернення: 24.10.2021).

2. Касперович Ю.В. Фіскальна безпека держави в умовах гібридної війни: аналітична доповідь. Київ : Фенікс, 2019. 128 с.

3. Валовий внутрішній продукт України за період 2011-2020 років. URL: https://index.minfin.com.ua/economy/gdp/ (дата звернення: 25.10.2021).

4. Звіти про виконання видатків Державного бюджету України за 2011-2020 роки. URL: https://www.treasury.gov.ua/ua/file-storage/vikonannya-derzhavnogo-byudzhetu (дата звернення: 25.10.2021).

5. Експерти назвали найбільш серйозні загрози суверенітету України. URL: https://www.unian.ua/politics/380152-eksperti-nazvali-naybilsh-seryozni-zagrozi-suverenitetu- 
ukrajini.html (дата звернення: 25.10.2021).

6. Звіт Тимчасової слідчої комісії Верховної Ради України для проведення розслідування відомостей щодо фактів розкрадання в Збройних Силах України та підриву обороноздатності держави у $\begin{array}{lllllll}\text { період } & 3 & 2004 & \text { по } 2017 \text { роки. Перша частина. }\end{array}$ https://www.ukrmilitary.com/2019/06/rozkradannya-zvit-1.html (дата звернення: 28.10.2021).

7. Власюк О.С. Національна безпека України: еволюція проблем внутрішньої політики: вибр. наук. праці. Київ : НІСД, 2016. 528 с.

8. Кириленко О.П. Сучасні тенденції видатків на оборону з державного бюджету України. Свiт фінансів. 2019. № 3(60). С. 179-188.

9. Радіонов Ю.Д. Виконання Державного бюджету України в умовах пандемії COVID-19. Фінанси України. 2021. № 9. С. 52-69.

10. Чеберяко О.В., Варналій 3.С. Фінансові передумови та оцінка фінансування оборони в умовах російсько-української гібридної війни. Науковий вісник Полісся. 2017. № 4 (12). Ч. 1. С. 143-149.

\section{References}

1. Budget Code of Ukraine: The Law of Ukraine. Verkhovna Rada of Ukraine, zakon.rada.gov.ua/laws/show/2456-17\#Text. Accessed 24 Oct. 2021.

2. Kasperovych, Yu.V. Fiscal security of the state in the conditions of hybrid war: analytical report. Kyiv, 2019.

3. "Gross domestic product of Ukraine for the period 2011-2020". Minfin, index.minfin.com.ua/economy/gdp/. Accessed 25 Oct. 2021.

4. Reports on the implementation of expenditures of the State Budget of Ukraine for 2011-2020". treasury.gov, www.treasury.gov.ua/ua/file-storage/vikonannya-derzhavnogo-byudzhetu. Accessed 25 Oct. 2021.

5. "Experts named the most serious threats to Ukraine's sovereignty". Unian, www.unian.ua/politics/380152eksperti-nazvali-naybilsh-seryozni-zagrozi-suverenitetu-ukrajini.html. Accessed 25 Oct. 2021.

6. Report of the Temporary Commission of Inquiry of the Verkhovna Rada of Ukraine to investigate information on thefts in the Armed Forces of Ukraine and undermining the state's defense capabilities in the period from 2004 to 2017. The first part. Ukrmilitary, www.ukrmilitary.com/2019/06/rozkradannyazvit-1.html. Accessed 28 Oct. 2021.

7. Vlasiuk, O.S. National security of Ukraine: the evolution of domestic policy problems: selected research papers. Kyiv, 2016.

8. Kyrylenko, O.P. "Current trends in defense spending from the state budget of Ukraine". The world of finance, no. 3(60), 2019, pp. 179-188.

9. Radionov, Yu.D. "Execution of the State Budget of Ukraine in the conditions of the COVID-19 pandemic". Finance of Ukraine, no. 9, 2021, pp. 52-69.

10. Cheberiako, O.V., Varnalii, Z.S. "Financial preconditions and assessment of defense financing in the conditions of the Russian-Ukrainian hybrid war”. Scientific Bulletin of Polissya, vol. 1, no. 4 (12), 2017, pp. 143-149.

УДК 336.15

doi: 10.15330/apred.2.17.67-76

Смець О.І. ${ }^{1}$ Білошкурська Н. В. ${ }^{2}$

ПОЛІТЕКОНОМІЧНІ ОСОБЛИВОСТІ ДЕРЖАВНО-ПРИВАТНОГО ПАРТНЕРСТВА

\footnotetext{
${ }^{1}$ Прикарпатський національний університет імені Василя Стефаника,

Міністерство освіти і науки України, кафедра теоретичної і прикладної економіки, вул. Шевченка, 57, м. Івано-Франківськ, 76018,Україна, тел.: +380979040894, e-mail: olaif2005@gmail.com, ORCID: 0000-0003-1338-2880
} 